\title{
Blade type nails cause more varus collapse than screw type nails in the treatment of elderly trochanteric fractures
}

\section{Yaşlı hastalarda trokanterik kırıkların tedavisinde bıçak tipi çiviler vida tipi çivilere göre daha fazla varus kollapsa neden olur}

\author{
Mustafa Caner Okkaoğlu ${ }^{1}$ (D), Yüksel Uğur Yaradılmış ${ }^{2^{*}}$ (D), İsmail Demirkale ${ }^{1}$ (D), Hakan Şeşen ${ }^{1}$ (D), \\ Mahmut Özdemir ${ }^{3}$ iD, Murat Altay ${ }^{1}$ \\ ${ }^{1}$ University of Health Sciences, Keçiören Health Practice and Research Center Orthopaedics and Traumatology Department Ankara, Turkey \\ ${ }^{2}$ Çankırı State Hospital, Orthopaedics and Traumatology Department Çankırı, Turkey \\ ${ }^{3}$ Tunceli State Hospital Orthopaedics and Traumatology Department Tunceli, Turkey \\ * Corresponding author: Yüksel Uğur Yaradılmış E-mail: ugur_yaradilmis@outlook.com ORCID: 0000-0002-7606-5690 \\ Received: 31 July 2019 Accepted: 23 August 2019
}

\begin{abstract}
Aim: Blade and screw type nail designs are widely used in the treatment of trochanteric fractures. Although, blade designs were put as last generation nails on the market, it remains unclear which design has better clinical and radiographic outcomes. The purposes of our study were to compare two cephalo medullary nail designs as helical blade and lag screw type for trochanteric fractures (AO/OTA 31-A type fractures), to analyse and compare clinical and functional outcomes, complication rates.
\end{abstract}

Material and Methods: This study comprised 101 patients with trochanteric fractures treated with either proximal femoral nail antirotation (PFNA) as blade type nail, or Peritrochanteric nail (PTN) as screw type nail for a minimum of 6 months. We assessed comorbidities, fracture type pre-operatively, operation time, blood loss, reduction quality, tip apex distance intra and post operatively, medical and mechanical complications, partial, full weight bearing time, Harris hip scores and Short form 36 scores and mortality during follow up period.

Results: There was no significant difference in the operation time, blood loss, total mechanical or medical complications, partial, full weight bearing time, mortality rate, and Harris Hip scores of PTN or PFNA groups. Lateral migration and varus collapse rates of patients treated with PFNA were significantly higher than patients treated with PTN. However particular SF 36 scores of PFNA group were significantly higher than PTN group.

Conclusion: Blade type nail designs caused more varus collapse than screw type nails in the treatment of elderly trochanteric fractures, however these radiographic complications didn't influence on clinical outcomes of patients.

Keywords: elderly, trochanteric fractures, blade type nail, screw type nail, varus collapse

() 2020 by the authors; licensee MEDITAGEM Ltd., Turkey. This article is an open access article distributed under the terms and conditions of the Creative Commons Attribution License (http://creativecommons.org/licenses/by/4.0/). 


\section{öz}

Amaç: Bıçak ve vida tipi çivi tasarımları trokanterik kırıkların tedavisinde yaygın olarak kullanılmaktadır. Her ne kadar bıçak tasarımları piyasada son nesil çiviler olarak kullanılıyor olsa da, hangi tasarımın daha iyi klinik ve radyografik sonuçlara sahip olduğu belirsizliğini koruyor. Bu çalışmada yaşlı trokanterik kırıklarında(AO / OTA 31-A tipi kırıklar) bıçak ve vida tipi sefalomedüller çivi tasarımlarının, klinik ve fonksiyonel sonuçlarını ve komplikasyon oranlarını karşılaştırmayı amaçladık.

Gereç ve Yöntemler: Bu çalışmaya, en az 6 ay takibi olan, vida tipi çivi olarak Peritrochanteric Nail (PTN) veya bıçak tipi çivi olarak Proximal Femoral Nail Antirotation (PFNA) ile tedavi edilen trokanterik kırığı olan 101 hasta dahil edildi. Çalışmamızda komorbiditeleri, ameliyat öncesi kırık tiplerini, operasyon süresini, kan kaybını, redüksiyon kalitesini, uç apex mesafesini intra ve post operatif olarak, medikal ve mekanik komplikasyonları, mortaliteleri, kısmi, tam yük verebilme sürelerini, Harris kalça skorlarını ve Kısa Form 36 skorlarını analiz ettik ve karşılaştırdık

Bulgular: Operasyon süresi, kan kaybı, total mekanik veya medikal komplikasyonlar, kısmi, tam yük verme süresi, mortalite oranı ve Harris Kalça skorları açısından PTN veya PFNA grupları arasında anlamlı fark yoktu. PFNA ile tedavi edilen hastaların lateral migrasyon ve varus çökme oranları PTN ile tedavi edilen hastalara göre anlamlı derecede yüksekti. Bununla birlikte, PFNA grubunun özellikle SF 36 skorları PTN grubundan anlamlı derecede yüksekti.

Sonuç: Bıçak tipi çivi tasarımları yaşlı trokanterik kırıkların tedavisinde vida tipi çivilere göre daha fazla varus çökmesine neden olmuştur, ancak bu radyografik komplikasyonlar hastaların klinik sonuçları üzerinde etkili olmamıştır.

Anahtar kelimeler: yaşlı, trokanterik kırıklar, bıçak tipi çiviler, vida tipi çiviler, varus kollaps

\section{INTRODUCTION}

Hip fractures constitute one of most common fractures related to osteoporosis [1]. Trochanteric fractures are forty five percent of these fractures [2,3]. Due to ageing population, the incidence of trochanteric fractures is expected to continue to increase. The goal of treatment in these fractures is stable fixation and immediate mobilisation for preventing complications as deep vein thrombosis, pulmonary embolism and cardiovascular events $[4,5]$.

For many years, a lot of treatment modalities have been used for trochanteric fractures. Sliding hip screws, hemiarthroplasty were the most common ones. Unfortunately, it is reported that, sliding hip screw has had $8 \%-13 \%$ failure rate $[6,7]$. Hemiarthroplasty is another modality of treatment especially for trochanteric fractures in older patients with severe osteoporosis $[8,9]$. In a recent prospective randomized study compared proximal femoral nail with hemiarthroplasty, nailing has had superior clinical outcomes [10]. Now, an increasing interest emerged on nails and their variable designs in trochanteric femur fractures. Several studies about comparison of nail designs were published [11-20]. Helical designs and screw type designs are mostly compared ones. However, it is still unclear which design has better clinical, radiographic outcomes and complication rate.
The purpose of this study was to investigate clinical, radiological outcomes of cephalomedullary nails with helical blade and lag screw, to compare complication rates in the treatment of trochanteric fractures.

\section{MATERIALS AND METHODS}

Informed consent of all patients was obtained and the study was approved by institutional review board. A total of 178 patients with trochanteric fractures were treated from September 2010 to April 2014. In our study; inclusion criteria were: (a) minimum 6 month follow up, (b) using PFNA or PTN as cephalomedullary nail type. Patients with less than 6 months follow up and treated with dynamic hip screw, hemiarthroplasty and other cephalomedullary nails were excluded. After all inclusion criteria performed, 101 patients were included in the study.

The patients were assigned to undergo either PFNA (Synthes GmbH, Oberdorf, Switzerland) or PTN (Biomet, Warsaw, Indiana, USA) fixation according to physician's decision. Closed reduction and internal fixation with cephalomedullary nail on a standard radiolucent table under image intensifier control was performed in all patients. We used $130^{\circ}$ nails with helical blade or lag screw, which were inserted in to lower half of femoral head on anteroposterior view and in the middle on lateral view. In PTN group, we used telescoping lag screws other than reverse oblique fractures. In reverse oblique fractures we 
Table 1. Fogagnolo's reduction criteria [22]

\begin{tabular}{|c|c|}
\hline Criteria of Reduction in Trochanteric Fractures according to Fogagnolo et al. \\
\hline $\begin{array}{c}\text { Alignment; } \\
\text { Antero-Posterior view }\end{array}$ & Normal cervico-diaphyseal angle or slight valgus \\
\hline Alignment \\
Lateral view & $<20^{\circ}$ angulation \\
\hline Displacement & $\begin{array}{c}\text { More than \%80 overlapping in both planes } \\
\text { Less than } 5 \mathrm{~mm} \text { of shortening }\end{array}$ \\
\hline
\end{tabular}

used solid lag screw. One distal static interlocking screw was performed in all patients. All surgeries were performed by two senior attending surgeons.

Patients with proper fracture reduction, medial cortex continuity were allowed tolerable full weight bearing on the day after surgery, others were allowed partial weight bearing with walker or crutches for minimum 6 weeks postoperatively until fracture union. Prophylactic antibiotics were administered, and prophylactic low molecular weight heparin was given subcutaneously for four weeks postoperatively. The patients were discharged from hospital after mobilisation and medical healthiness.

The Patients' records, including age, gender, American Society of Anaesthesiologists (ASA) class rating, comorbidities, and fracture type according to AO/OTA Classification were collected. Reduction quality and implant position were recorded postoperatively. Follow up after operation was undertaken at 1, 3, 6, 12 months and yearly thereafter. Anteroposterior and lateral plain radiographs were taken at each visit.

Comorbidities were evaluated according to Charlson comorbidity index [21]. In this evaluation, coronary heart disease, heart failure, peripheral vascular diseases, chronic pulmonary disease, connective tissue disease, mild liver disease and diabetes mellitus score were assessed as one point, hemiplegia, moderate or severe kidney disease, end organ disease of diabetes, tumour, lymphoma, leukaemia were two point, moderate and severe liver disease were three point, metastatic tumour and AIDS were assessed as six points. The patients were grouped as patients with 0-1 points or $\geq 2$ points.

Fracture reduction quality were evaluated using Fogagnolo's reduction criteria (Table 1) [22]. Another radiographic evaluation parameter was Baumgartner's tip apex distance [23]. $25 \mathrm{~mm}$ was cut off level for implant position assessment. All patients included in this study had acceptable or good reduction quality and $<25 \mathrm{~mm}$ of Baumgartner's tip apex distance. Another implant position assessment tool was Cleveland index [24]. Zone 5 was accepted as desirable implant position.
Postoperatively, patients' last follow up Short Form 36 and Harris Hip Scores were collected $[25,26]$. Complications after operation were grouped as medical and mechanical. Both blade and screw group were compared with each other.

For both groups, data were represented as mean and standard deviation (SD) for continuous response variables, or numbers and percentages for discrete variables. For discrete variables, chi-square test was used to compare the differences between the two groups, whereas for continuous variables, Student's t-test was used. SPSS Statistics 20.0 was used for the statistical analysis, and differences were considered to be statistically significant when $\mathrm{p}$ values were $<0.05$.

\section{RESULTS}

Totally 58 patients were performed PTN, 43 patients were performed PFNA and 20 of all patients died at follow up. The mean follow up time of PFN-A and PTN group was $14.72 \pm$ 7.37 and $12.93 \pm 8.41$ respectively. Eight patients went to revision because of mechanical complications. Therefore, only rest of the patients $(n=73)$ were included for evaluating functional and health outcomes.

Pre-operative characteristics of patients who were treated with either PTN or PFN-A were similar and not statistically different in terms of sex, age and AO fracture subtype classification distribution (Table 2). In addition to these variables, we included Charlson co-morbidity index and ASA scores to find that if there is any standardization error may also affect post-operative SF-36 scores and mortality rates for comparing PTN and PFN-A groups. However, there was no statistical difference between the groups in terms of these two variables too ( $p>0.05$ ) (Table 2). 
Table 2. Pre-operative characteristics of patients who were treated with either PTN or PFN-A

\begin{tabular}{|c|c|c|}
\hline & PTN (n=58) & PFN-A (n=43) \\
\hline Age (Mean \pm SD) & $78.24 \pm 9.86$ & $28 / 15$ \\
\hline Sex (Female/Male ratio) & $38 / 20$ & 1.86 \\
\hline Charlson Co-morbidiy Index $<2$ & 1.9 & 22 \\
\hline Charlson Co-morbidity Index $\geq 2$ & 31 & 20 \\
\hline AO fracture subtype & 28 & $17(39.5 \%)$ \\
31-A1 & $27(46.5 \%)$ & $12(60.5 \%)$ \\
\hline AO fracture subtype & $31(53.5 \%)$ & $13.6 \pm 4.35$ \\
\hline 31-A2 and A3 & $11.8 \pm 3.82$ & \\
\hline Follow up period (months) & & \\
\hline
\end{tabular}

Table 3. Tip-apex Distance and Reduction Quality Analysis

\begin{tabular}{|c|c|c|}
\hline Measurements & PTN, $n=58$ & PFNA, $n=43$ \\
\hline Tip-apex distance $(\mathrm{mm})($ mean $\pm \mathrm{SD})$ & $23.1 \pm 4.2$ & $23.8 \pm 4.5$ \\
\hline Tip-apex distance $\leq 25 \mathrm{~mm}(\%)$ & $48(82.75)$ & $36(83.72)$ \\
\hline Patients with "Acceptable" or "Good" reduction Quality n(\%) & $54(93.1)$ & 40 (93.2) \\
\hline Zone 5 according to Cleveland index (\%) & $42(72.4)$ & $30(69.8)$ \\
\hline
\end{tabular}

Table 4. Comparison of post-operative parameters, complication rates and mortality of PTN and PFNA groups

\begin{tabular}{|c|c|c|c|c|}
\hline Parameters & PTN group & PFN-A group & P values & All patients \\
\hline & $n=58$ & $n=43$ & & $N=101$ \\
\hline Operation time & $44.07 \pm 15.13$ minute & $45.07 \pm 17.31$ minute & 0.52 & $44.51 \pm 16.26$ minute \\
\hline Blood loss(Decrease of $\mathrm{Hb}$ ) & $1.86 \pm 1.21 \mathrm{mg} / \mathrm{dl}$ & $1.92 \pm 1.24 \mathrm{mg} / \mathrm{dl}$ & 0.73 & $1.89 \pm 1.22 \mathrm{mg} / \mathrm{dl}$ \\
\hline Mechanical complication & $6(10.4 \%)$ & $9(20,9 \%)$ & 0.16 & $14(13.9 \%)$ \\
\hline Cut out & $4(6.9 \%)$ & $4(9.3 \%)$ & 0.46 & $8(7.9 \%)$ \\
\hline Lateral sliding & $0(0 \%)$ & $4(9.3 \%)$ & 0.03 & $4(3.9 \%)$ \\
\hline Varus collapse & $1(1.7 \%)$ & $5(11.6 \%)$ & 0.049 & $6(5.9 \%)$ \\
\hline Complications caused revision & $4(6.9 \%)$ & $4(9.3 \%)$ & 0.11 & $10(7.9 \%)$ \\
\hline First 3 month mortality & $5(8.6 \%)$ & $6(13,9 \%)$ & 0.52 & $11(10.9 \%)$ \\
\hline First 6 month mortality & $8(13.7 \%)$ & $7(16.2 \%)$ & 0.95 & $15(14.9 \%)$ \\
\hline
\end{tabular}

Post-operative reduction and screw or blade position qualities were analysed. All parameters were similar in both groups (Table 3).

Operation time (PTN group; 88.07 vs PFNA group; 90.12 min), blood loss in terms of haemoglobin decrease (PTN; $1.86 \mathrm{mg} / \mathrm{dl}$ vs PFNA; $1.92 \mathrm{mg} / \mathrm{dl}$ ), partial and full weight bearing time (PTN; 2.58, 30.09 days vs PFNA; 2.64, 36.93 days) were similar and statistically not different in both groups. In helical blade group (PFNA group) we have shown more mechanical complication rates like cut out, lateral sliding, varus collapse. However, significant difference was only seen in varus collapse and lateral sliding ( $p=0.03$ and 0,049). Although helical blade group has more complications in some terms, there was no difference in overall revision rates (6.9\% vs $9.3 \%, p=0.11$ ) (Table 4).

In this study we also compared early mortality rates may be related to surgery, and classified as first 3 month and 6 month mortality rates. Helical blade group mortality rate was $13.9 \%$ in first three month and $16.1 \%$ in first six-months, screw group mortality rate was $8.6 \%$ in first three months, and $11.9 \%$ in first six-months. There was no significant difference statistically ( $p=0.52$ ) (Table 4).

We used 2 major scoring modalities for evaluating hip functional outcomes and general health outcomes after these two different proximal femoral nail design usages: Harris Hip Score and Short Form 36. When we compared the last follow up Harris Hip scores, there was no significant difference between two groups as mean scores and distribution of excellent/good, fair, bad scored patient numbers $(p=0.21,0.79,0.39,0.75)$. However, when we compare SF 36 subgroups like physical function, general health and social function, we showed superiority of PFNA group ( $p<0.05)$ (Table 5). 
Table 5. Comparison of post-operative functional and clinical parameters of PTN and PFNA groups

\begin{tabular}{|c|c|c|c|c|}
\hline Parameters & PTN group & PFN-A group & P values & All patients \\
\hline & $n=45$ & $n=28$ & & $N=73$ \\
\hline Partial weight bearing time (mean) & 2.58 day & 2.64 day & $0.78^{* * *}$ & 2.60 day \\
\hline Full weight bearing time (mean) & 30.09 day & 36.93 day & $0.96^{* * * *}$ & 32.73 day \\
\hline Harris Scores (mean) & $76.03 \pm 8.89$ & $79.19 \pm 2.33$ & $0.21^{* * *}$ & $77.24 \pm 10.28$ \\
\hline Harris Scores (Excellent-Good) & $23(51.1 \%)$ & $16(57.1 \%)$ & 0.79 & 39 (53.4\%) \\
\hline Harris Scores (Fair) & $15(33.3 \%)$ & $8(28.5 \%)$ & 0.39 & $23(31.5 \%)$ \\
\hline Harris Scores (Bad) & $7(15.5 \%)$ & $4(14.2 \%)$ & 0.75 & $11(15.1 \%)$ \\
\hline Parker and Palmer Scores & $6.51 \pm 1.05$ & $6.71 \pm 1.24$ & 0.34 & $6.59 \pm 1.14$ \\
\hline \multicolumn{5}{|l|}{ SF-36 Parameters; } \\
\hline Physical function & $28,11 \pm 19,14$ & $42,32 \pm 30,47$ & 0,032 & $33,56 \pm 24,91$ \\
\hline Role physical & $18,33 \pm 21,59$ & $32,14 \pm 34,6$ & 0,127 & $23,63 \pm 27,92$ \\
\hline Bodily pain & $60,66 \pm 19,65$ & $69,04 \pm 23,77$ & 0,312 & $63,86 \pm 21,56$ \\
\hline General Health & $41,13 \pm 15$ & $51,11 \pm 19,60$ & 0,017 & $44,96 \pm 17,48$ \\
\hline Social function & $51,39 \pm 22,49$ & $65,63 \pm 24,44$ & 0,021 & $56,85 \pm 24,12$ \\
\hline Role emotional & $36,44 \pm 35,27$ & $55,95 \pm 42,61$ & 0,056 & $43,93 \pm 39,14$ \\
\hline Mental health & $55,64 \pm 14,96$ & $60,57 \pm 15,50$ & 0,181 & $57,53 \pm 15,26$ \\
\hline Physical Component Summary & $31,42 \pm 7,14$ & $35,98 \pm 10,72$ & 0,059 & $33,17 \pm 8,91$ \\
\hline Mental Component Summary & $41,08 \pm 9,24$ & $45,08 \pm 10,25$ & 0,089 & $42,61 \pm 9,77$ \\
\hline
\end{tabular}

\section{DISCUSSION}

An increasing interest emerged on nails and their variable designs in trochanteric femur fractures. Proximal femoral nail antirotation (PFNA) as a superior generation nail design (helical blade adapted) and peritrochanteric nail (PTN) as previous generation nail design (lag screw adapted) are widely used in trochanteric fractures and both of these commercial products are preliminary designs of helical blade and screw lag screws. It's still unclear which design has better clinical, radiographic outcomes and complication rate. The purpose of this study was to investigate clinical, radiological outcomes of cephalomedullary nails with helical blade and lag screw, to compare complication rates in the treatment of trochanteric fractures.

This study has some limitations. Firstly, our study was a retrospective study. Therefore, functional and life quality outcomes were only evaluated in the last follow up for this study, so we couldn't show improvement process in the follow up period. Secondly, number of patients in our study was not large enough, this caused statistically insignificance in several terms despite quantitative significance. Thirdly our minimum follow up period was short, longer term minimum follow up time will give more accurate results. Finally, we evaluated all of the patients not focusing on stable or unstable fractures but we classified the cases according to AO fracture type in the groups and compared if there was any difference between two groups for standardization.
The main finding of this study was helical blade type proximal femoral nail design systems caused more varus collapse and lateral sliding than screw type nail designs, although helical blade group had better results in some terms of SF 36 scores, and no more revisions than other group.

In the literature, trochanteric fracture treatment is still controversial. This debate exists especially in proximal femoral nailing designs. In the literature there are several biomechanical and clinical studies related to comparison of helical and screw type cephalomedullary nails [11-20]. Strauss, Sommers et al. and Al Munjjed et al. showed biomechanical advantages of helical blades over screw type nails, because of their superior contact with cancellous bone and better torque resistance to rotational forces that may provide to prevent cut out of screw or blade [11-13]. However, Al Munjjed et al. also showed that if torque resistance to rotational forces are somehow exceeded, blade will go on to cut out with more destructive damage to femoral head [12]. Windolf et al. showed similar results and added that because of more damage to femoral head, varus collapse of femoral neck and lateral sliding is seen more in blade type cephalomedullary nails [14]. Besides these biomechanical studies in a clinical study D' Arrigo et al. reported that screw type designs have more blood loss, operation time, cut out, mechanical and medical complication rate and similar mortality rate and clinical outcome. However, in D' Arrigo's study, blade group has more secondary varus alignment consistent with Windolf et al. $[14,15]$. Stern et al. and Lenich et al. reported that blade type cephalomedullary nails are superior to screw type nails 


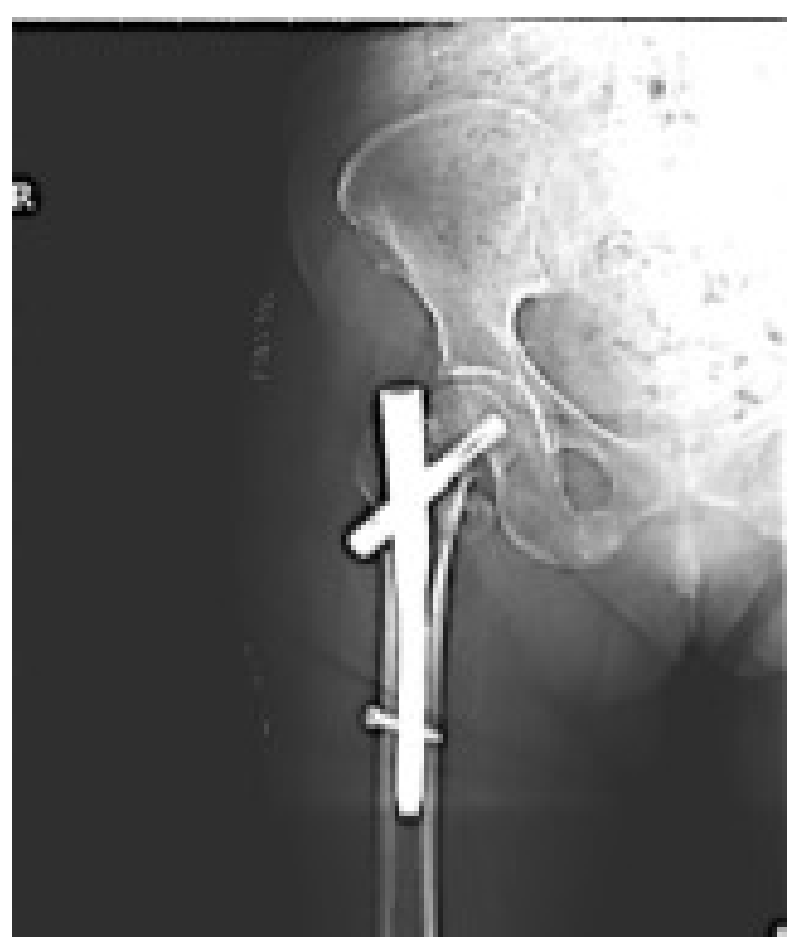

Figure 1.88 year old female with trochanteric fracture progressing to varus collaps and lateral sliding with helical blade design implant

in their clinical studies [16,17]. Vaquero et al, Yaozeng et al. and Yang et al. reported similar results in both blade and screw groups [18-20].

In our study, both groups had similar results after surgery in terms of mortality, total mechanical complication rates, operation time, partial and full weight bearing time, blood loss. Harris hip mean scores and distribution of excellent, good, fair and bad scored classification were also similar in both groups. This study reported that blade type cephalomedullary nails provided similar or better clinical and functional outcome.

The main finding was reported as helical blade type proximal femoral nail design systems caused more varus collapse and lateral sliding but no more cut out than screw type nail designs and it is consistent with few previous studies $[12,14,15]$. However blade group had similar revision rates with screw group. It shows that varus collapse and lateral sliding cases of blade group didn't cause revision (Figure 1). Contrarily, blade group has better results in physical function, general health, social function subgroup of SF36 scores. These subgroups projects mobilization of patient and perception of health [26]. It may be attributed that, helical blades are very stable implants, thanks to this rotational stability, have better clinical and functional outcome but somehow it fails, they cause more bone loss, and due to lack of locking mechanism of blade, advance to varus collapse and lateral sliding.

\section{CONCLUSION}

Our study pointed out that blade type cephalomedullary nails causes more varus collaps and lateral sliding complications than screw nails but it does not affect revision rates. On the contrary, blade designs have better or similar functional and clinical outcomes compared to screw type. Prospective, larger size of sample and longer term follow up further studies are required for evaluating superiority of two designs on each other.

\section{DECLARATION OF CONFLICT OF INTEREST}

The authors received no financial support for the research and/or authorship of this article. There is no conflict of interest.

\section{REFERENCES}

1. Ghafoori S, Keshtkar A, Khashayar P. The risk of osteoporotic fractures and its associating risk factors according to the FRAX model in the Iranian patients: a follow-up cohort. J Diabetes Metab Disord 2014:22;13(1):93.

2. Allfram PA. An epidemiological study of cervical and trochanteric fractures of the femur in an urban population. Analysis of 1,664 cases with spe-cial reference to etiologic factors. ActaOrthop Scand Suppl 1964;65:Suppl65:1-109.

3. Gallagher JC, Melton LJ, RiggsBL, Bergstrath E. Epidemiology of the fractures of the proximal femur in Rochester, Minnesota. Clin OrthopRelat Res 1980:(150):163-71.

4. DeLee JC. Fractures and Dislocations of the Hip, Rockwood and Green's Fractures in Adults Vol.2; Lippincott-Raven 1996:1659-827.

5. Green S, Moore T. Bipolar prosthetic replacement for the management of unstable inter trochanteric hip fractures in the elderly. Clin Orthop 1987;224:168-77.

6. Bannister GC, Gibson AG, Ackroyd CE, Newman JH. The fixation and prognosis of trochanteric fractures. A randomized prospective controlled trial. Clin Orthop Relat Res 1990;254:242-6.

7. Simpson AH, Varty K, Dodd CA. Sliding hip screws: modes of failure. Injury 1989;20:227-31.

8. Haentjens P, Lamraski G. Endoprosthetic replacement of unstable, comminuted intertrochanteric fracture of the femur in the elderly, osteoporotic patient: a review. Disabil Rehabil 2005;27:1167-80. 
9. Rockwood, C. Intertrochanteric fractures. Rockwood and Green's fractures in adults (6th ed., Vol. 2, p. 1807,1808). Philadelphia: Lippincott Williams \& Wilkins. 2006.

10. Kim SY, Kim YG, Hwang JK. Cementless calcarreplacement hemiarthroplasty compared with intramedullary fixation of unstable intertrochanteric fractures. A prospective, randomized study. J Bone Joint Surg Am 2005;87:2186-92.

11. Strauss E, Frank J, Lee J, Kummer FJ, Tejwani N. Helical blade versus sliding hip screw for treatment of unstable intertrochanteric hip fractures: a biomechanical evaluation. Injury 2006;37(10):984-9.

12. Al-Munajjed AA, Hammer J, Mayr E, Nerlich M, Lenich A. Biomechanical characterisation of osteosyntheses for proximal femur fractures: helical blade versus screw. Stud Health Technol Inform 2008;(133):1-10.

13. Sommers MB, Roth $C$, Hall H, Kam BC, Ehmke LW, Krieg JC, Madey SM, Bottlang M. A laboratory model to evaluate cutout resistance of implants for pertrochanteric fracture fixation. J Orthop Trauma 2004;18(6):361-8.

14. Windolf M, Braunstein V, Dutoit C, Schwieger K. Is a helical shaped implant a superior alternative to the Dynamic Hip Screw for unstable femoral neck fractures? A biomechanical investigation Clinical Biomechanics 2009; 24(1):59-64.

15. D'Arrigo C, Carcangiu A, Perugia D, Scapellato S, Alonzo $\mathrm{R}$, Frontini $\mathrm{S}$, Ferretti A. Intertrochanteric fractures: comparison between two different locking nails International Orthopaedics (SICOT) 2012:36:2545-51.

16. Lenich A, Vester $H$, Nerlich M, Mayr E, Stöckle U, Füchtmeier B. Clinical comparison of the second and third generation of intramedullary devices for trochanteric fractures of the hip Blade vs Screw. Injury 2010;41(12):1292-6.

17. Stern R, Lübbeke A, Suva D, Miozzari $H$, Hoffmeyer P. Prospective randomised study comparing screw versus helical blade in the treatment of low-energy trochanteric fractures International Orthopaedics (SICOT) 2011:35:1855-61.
18. Yang $\mathrm{Y}-\mathrm{H}$, Wang $\mathrm{Y}-\mathrm{R}$, Jiang S-D, Jiang L-S. Proximal femoral nail antirotation and third-generation Gamma nail: which is a better device for the treatment of intertrochanteric fractures? Singapore Med J 2013; 54(8): 446-4.

19. Vaqueroa J, Munoza J, Pratb S, Ramirezc C, Aguadod HJ, Morenoe E, Perezf MD. Proximal Femoral Nail Antirotation versus Gamma3 nail for intramedullary nailing of unstable trochanteric fractures. A randomised comparative study Injury, Int. J. Care Injured 2012;43(S2):47-54.

20. Xu Y, Geng D, Yang H, Zhu G, Wang X. Comparative study of trochanteric fracture treated with the proximal femoral nail anti-rotation and the third generation of gamma nail Injury, Int. J. Care Injured 2010:41;1234-8.

21. Charlson ME, Pompei P, Ales KL, MacKenzie CR. A new method of classifying prognostic comorbidity in longitudinal studies: development and validation. J Chron Dis 1987;40:373-83.

22. Fogagnolo F, Kfuri M Jr, Paccola CA. Intramedullary fixation of pertrochanteric hip fractures with the short AO-ASIF proximal femoral nail. Arch Orthop Trauma Surg 2004;124(1):31-7.

23. Baumgaertner MR, Solberg BD. Awareness of tip-apex distance reduces failure of fixation of trochanteric fractures of the hip. J Bone Joint Surg Br 1997;79:969-71

24. Cleveland M, Bosworth DM, Thompson FR, Wilson HJ, Jr, Ishizuka T. A ten-year analysis of intertrochanteric fractures of the femur. J Bone Joint Surg Am. 1959;41$A(8): 1399-408$.

25. Harris WH. Traumatic arthritis of the hip after dislocation and acetabular fractures: treatment by mold arthroplasty. An end-result study using a new method of result evaluation. J Bone Joint Surg Am 1969;51(4):73755.

26. Ware JEJ, Sherbourne CD. The MOS 36-item short-form health survey (SF-36). I. Conceptual framework and item selection. Med Care 1992;30:473-83. 